\title{
Evidence of a reproduction-related function for pituitary adenylate cyclase-activating polypeptide-related peptide in an Anabantidae fish
}

\author{
G Levy ${ }^{1,2,3}$ and G Degani ${ }^{1,2}$ \\ ${ }^{1}$ School of Science and Technology, Tel-Hai Academic College, Upper Galilee 12210, Israel \\ ${ }^{2}$ MIGAL- Galilee Technology Center, Kiryat Shmona 11016, Israel \\ ${ }^{3}$ Department of Neurobiology, George S. Wise Faculty of Life Sciences, Tel Aviv University, Tel Aviv 69978, Israel \\ (Correspondence should be addressed to G Degani at MIGAL- Galilee Technology Center; Email: gad@migal.org.il)
}

\begin{abstract}
Pituitary adenylate cyclase-activating polypeptide (PACAP) is synthesized from a precursor, which includes the PACAPrelated peptide (PRP; formerly known as GHRH-like peptide). PRP can act as a hypophysiotropic factor in teleosts by stimulating GH secretion. However, no information points to this peptide as a regulator of reproduction. Recently, the blue gourami PRP-PACAP cDNA was cloned and found to be expressed in the brain. Thus, the aims of the present study were to investigate the PRP-PACAP gene expression pattern during sexual behavior and oogenesis, and to learn its effect on pituitary hormonal transcription in pituitary cells. Examination of the PRP-PACAP expression profile during sexual behavior and oogenesis revealed that $P R P-P A C A P$ mRNA levels were higher in mature non-reproductively active males than in nest builders and juveniles; and higher in females with oocytes in the final maturation stage than in vitellogenic individuals. Stimulation of pituitary cells with blue gourami PRP (bgPRP) caused an increase in $\beta$ LH subunit transcription levels only in females, whereas in males, it only brought about a rise in GH mRNA levels. These data were further supported by the presence of PRP receptor in the pituitary cells. Therefore, we propose that as a hypophysiotropic factor in the blue gourami, bgPRP may act differently on the gonadotropic axes in females and males, up-regulating gonadotropin mRNA in females and GH mRNA in males. This research provides a basis for the further understanding of the integrative network that regulates growth and reproduction, which may contribute to hormonal treatments and manipulations in aquaculture.
\end{abstract}

Journal of Molecular Endocrinology (2011) 46, 101-110

\section{Introduction}

In teleosts, the somatotropic axis is regulated by numerous hypothalamic peptides, such as the newly identified GHRH (Lee et al. 2007) and pituitary adenylate cyclase-activating polypeptide (PACAP). Both peptides have been implicated as GH-releasing factors. In all vertebrates, PACAP is synthesized from a longer precursor, the PACAP-related peptide (PRP; formerly known as GHRH or GHRH-like peptide)-PACAP. The physiological role of PACAP in reproduction and growth has been studied in detail, whereas information related to PRP function remains unknown. In non-mammalian vertebrates, a short alternatively spliced variant, lacking most of the PRP sequence, can be produced by an exon-skipping mechanism (Tam et al. 2007). Based on a sequence comparison, both peptides were classified as belonging to the secretin/glucagon superfamily (Sherwood et al. 2000). Sequence analysis revealed that PACAP is the most highly conserved member of this family, whereas
PRP is highly variable, from teleosts to mammals, both in sequence and length (Vaudry et al. 2009).

Although significant studies have been made of the structural and functional evolution of the PRP peptide, its physiological role as a regulator of growth and reproduction in teleosts has received little attention and is not fully understood.

Different immunoreactive (ir) neuronal populations of PRP in various brain regions of teleosts have been reported. Antiserum, directed against PRP, reacts with the pituitary in the pars distalis cell bodies and with neuronal cell bodies in the hypothalamus that project axonal pathways toward the median eminence and terminate primarily in the pars nervosa in Gadus morhua (Pan et al. 1985) and rainbow trout (Luo \& McKeown 1989). In addition, in the zebrafish, ir-PRP recognized fibers that probably originated from the gustatory/visceral nucleus and innervated the ventral area of the telencephalon, hypothalamus, and the spinal cord (Castro et al. 2009). In Salmonidae (chum salmon and coho salmon), ir-PRP was identified at the 
terminal nerve ganglion system, associated with the olfactory nerve and superficial basal regions of the olfactory bulbs (Parker \& Sherwood 1990), and fibers containing ir-PRP have been found in the proximal pars distalis in the vicinity of the somatotrophs in several teleost species (Olivereau et al. 1990, Rao et al. 1996). The physiological relevance of PRP as a hypophysiotropic factor has been further confirmed by the identification of a specific high affinity G-proteincoupled receptor (GPCR) of PRP in the goldfish and zebrafish pituitary (Castro et al. 2009). Binding PRP to this receptor can elicit a cAMP increase in PRP receptor-transfected cells, indicating that PRP may exert biological activities through a specific receptor. However, such receptors were not found in fish belonging to the perciformes order. Moreover, two genes encoding for the PRP receptor were identified in the zebrafish, fugu, and chicken (Cardoso et al. 2003, Fradinger et al. 2005, Wang et al. 2010).

Most studies in fish have focused on the involvement of PRP (formerly known as GHGH-LP or GRF) and PACAP in growth control. A recent study in the African catfish fry has shown that recombinant PRP enhanced growth promotion, as well as increasing the total protein concentration (Carpio et al. 2008). This ability may be related to the effect of GHRH on pituitary $\mathrm{GH}$, inducing protein synthesis and growth, which has been widely studied in teleosts. PACAP has a more potent effect on GH release than does PRP; however, such effects are varied among species. PRP can stimulate GH release from pituitary cells in several teleosts: goldfish (Vaughan et al. 1992), rainbow trout (Luo et al. 1990), and sockeye salmon (Parker et al. 1997), and a synthetic hexapeptide of PRP increased the cell number of rat GH-secreting cells (Goth et al. 1992). In contrast, in turbot (Psetta maxima) and zfGHRH-R-transfected CHO cells, PRP did not stimulate GH release (Montero et al. 2000, Rousseau et al. 2001, Lee et al. 2007).

Differential regulation during development and reproduction stages, as a result of the ratio between PACAP short and long variants, has been shown to occur in the turkey, suggesting that PRP may play an important role during hypothalamic development and reproduction (Yoo et al. 2000). The key regulators of reproduction at the pituitary levels are the gonadotropins. The effect of PACAP on gonadotropin release has been extensively studied in several teleosts, among them, the blue gourami (Levy et al. 2010), tilapia (Vaudry et al. 2009), and goldfish (Wong et al. 2000). However, the possible effect of PRP on gonadotropin regulation in fish remains obscure.

The blue gourami (Trichogaster trichopterus) belongs to the suborder Labyrinthici (characterized by the presence of an air-filled breathing cavity (the labyrinth), located above the gills under the operculum) and to the family Anabantidae. Among them, the blue gourami, which belongs to this genus, serves as a useful model in studying the role of endocrine regulation on reproduction, since it is multi-spawning and male dependent, with asynchronic ovary development (Jackson et al. 1994). Thus, each stage of its gonadal development can be controlled and examined separately in the laboratory (Degani 1993a,b, Jackson et al. 1999). The secretion and gene expression pattern of BFSH, $\beta$ LH (Degani et al. 1997, 2003a, Mananos et al. 1997, Jackson et al. 1999), and GH (Goldberg et al. 2004, Degani et al. 2006), as well as sex steroid secretion during gonadal development in male and female blue gourami, have been previously reported (Degani \& Boker $1992 a, b)$. Recently, our laboratory cloned the full length of the PRP-PACAP cDNA sequence, measured the mRNA expression profiles of PACAP in the blue gourami during different states of reproduction, and examined the role of PACAP in regulating pituitary hormone transcription (Levy et al. 2010).

Towards understanding the physiological role of PRP in growth and reproduction of teleosts, this study aimed to discover the changes in PRP-PACAP gene expression during oogenesis and sexual behavior in both males and females, as well as to investigate the potential hypophysiotropic effect of PRP on GH and gonadotropin gene expression in the blue gourami fish, in vitro. Our in vivo and in vitro results imply that PRP may be involved in the regulation of reproduction in teleosts, and provide an insight into its potential physiological roles.

\section{Materials and methods}

\section{Fish and sampling procedure}

Blue gourami fish (T. trichopterus), which were maintained and bred at MIGAL Laboratories in northern Israel, were used in this study. The fish were grown in containers $(2 \times 2 \times 0.5 \mathrm{~m})$ at a temperature of $27^{\circ} \mathrm{C}$ under a light regime of $12 \mathrm{~h}$ light:12 $\mathrm{h}$ darkness cycle (Jackson et al. 1994) and fed an artificial diet (45\% protein and $7 \%$ fat), supplemented by live food (Artemia salina). Brains were collected from females and males at various stages of gonadal development and the somatic and gonadal weights were recorded for the gonadosomatic index (GSI) calculations. The gonadal samples were processed for histological determination of the reproductive stage. The stages in females were previtellogenesis (PV; GSI $=0.911 \pm 0 \cdot 269)$, low vitellogenesis $(\mathrm{LV}$; $\mathrm{GSI}=3.93 \pm 1.351)$, high vitellogenesis (HV; GSI $=7 \cdot 893 \pm 1 \cdot 241)$, and maturation (MS; $\mathrm{GSI}=10 \cdot 901 \pm 2 \cdot 142$; Jackson et al. 1999). The stages in males were juvenile $(\mathrm{GSI}=0 \cdot 046 \pm 0 \cdot 014)$, mature nonreproductively active $(\mathrm{GSI}=0 \cdot 28 \pm 0 \cdot 03)$, and mature 
reproductively active (nest builders) $(\mathrm{GSI}=0 \cdot 33 \pm 0 \cdot 03)$ (Degani et al. 2003a).

\section{Histological analysis}

Gonadal samples were fixed in Bouin, and subsequently processed for light microscopy. Paraffin sections of $6 \mu \mathrm{m}$ were stained with hematoxylin and eosin, as previously described (Jackson et al. 1994).

\section{RNA extraction and cDNA synthesis}

Total RNA was extracted from freshly excised whole brains of males $(n=21)$ and females $(n=33)$, using Trizol reagent (Invitrogen), according to the manufacturer's recommendations. First-strand cDNA was synthesized by the Verso-Reverse-IT 1st Strand Synthesis Kit (ABgene, Epsom, UK) from 0.5 to $2 \mu \mathrm{g}$ total RNA, with an incubation of $1 \mathrm{~h}$ at $57{ }^{\circ} \mathrm{C}$, followed by $2 \mathrm{~min}$ at $94^{\circ} \mathrm{C}$.

\section{Partial cloning of the PRP receptor of the blue gourami pituitary}

Based on the full-length sequence of Danio rerio (accession number NM_001131052), Fugu rubripes (accession number AJ296145), and Carassius auratus (accession number AF048819), gene-specific primers were designed for the cloning of the partial cDNA sequence of the PRP receptor of the blue gourami brain (Table 1). The $5^{\prime}$ end PRP receptor was amplified by the SMART-RACE cDNA Amplification Kit, using the

Table 1 Nucleotide sequences of primers for pituitary adenylate cyclase-activating polypeptide-related peptide (PRP) and PRP receptor expression by reverse-transcribed $P C R(A)$ and for real-time PCR (B)

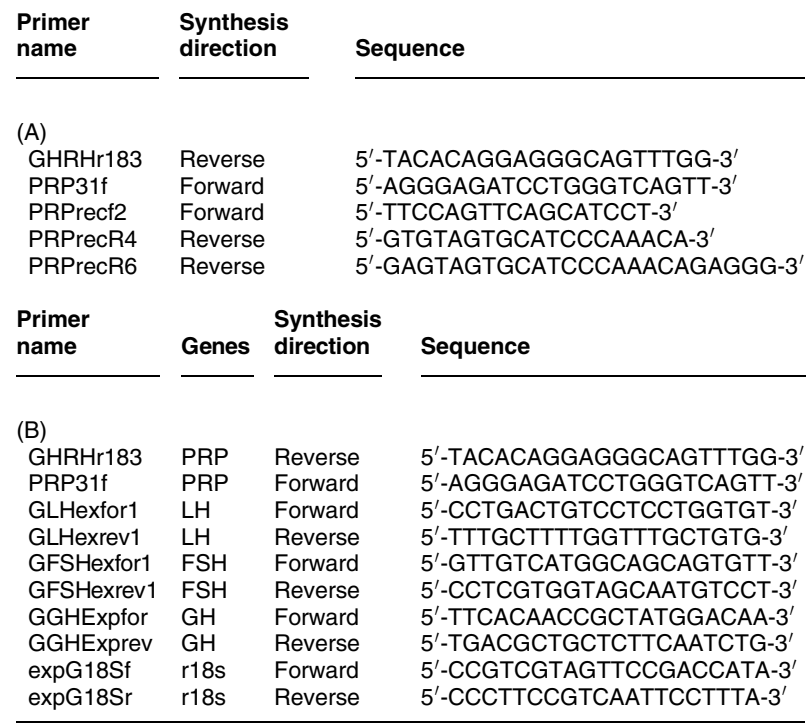

primer, PRPrecR4, according to the manufacturer's recommendations (Clontech). Following $5^{\prime}$ end amplification, nested PCR was performed using specific primers, PRPrecR4 and PRPrecf2. The amplified PCR product was cloned into the pGEM-T vector (Promega), which was propagated in Escherichia coli cells. The recombinant plasmid was then extracted using the SV miniprep (Promega), and the sequence of the amplified product was determined (HyLabs, Rehovot, Israel). Only one PRP receptor transcript was identified. The PCR was carried out in a total volume of $50 \mu$, consisting of $10 \times$ PCR buffer, $10 \mathrm{mM}$ each deoxynucleotide triphosphate, $1 \mu \mathrm{M}$ each primer, and $0.5 \mathrm{U}$ of Taq advantage 2 polymerase (Clontech), using the Thermal Cycler (Bio-Rad Laboratories, Inc.). The PCR products were visualized on a u.v. transilluminator after electrophoresis on a $2 \%$ agarose gel containing ethidium bromide. To confirm the specificity of the PCR, the identity of each PCR product was verified by sequencing.

\section{Amino acid sequence comparison between the blue gourami PRP and PRP receptor and the GHRH and GHRH receptor}

Multiple sequence alignment (Lasergene 6 software, DNASTAR, Madison, WI, USA) of the partial sequence of the blue gourami PRP (bgPRP) receptor with fish PRP receptor amino acid revealed that the blue gourami partial PRP receptor sequence shares an 84$91 \%$ identity with the amino acid sequence of the fish PRP receptor, and only $45 \%$ with the fish GHRH receptor. A comparison, between the amino acid sequences of mature bgPRP and the first 27 amino acids of GHRH of fish and mammals, demonstrated that PRP shares a 37\% identity with GHRH of fish and mammals. Sequence comparisons were employed using the ClustalW method.

\section{Expression of PRP-PACAP and its receptor in the brain and pituitary}

Reverse transcription (RT) was performed at $42^{\circ} \mathrm{C}$ for $2 \mathrm{~h}$ in a total volume of $10 \mu \mathrm{l}$, which consisted of $2 \mu \mathrm{g}$ total RNA from brain and pituitary tissues $(n=5-10)$ (Verso cDNA Kit, ABgene). The PCR was performed according to the manufacturer's instructions in a final volume of $50 \mu \mathrm{l}$, which contained 1 unit of Thermus aquaticus advantage 2 polymerase (Clontech). The primers used for PRP-PACAP and PRP receptor identification are summarized in Table 1 , and the $P R P-P A C A P$ primer locations are listed in Fig. 1A. The amplification programmes were for PRP-PACAP - 50 cycles of $94{ }^{\circ} \mathrm{C}$ for $30 \mathrm{~s} ; 50{ }^{\circ} \mathrm{C}$ for $60 \mathrm{~s} ; 72^{\circ} \mathrm{C}$ for $60 \mathrm{~s}$, followed by a $5 \mathrm{~min}$ final extension at $72^{\circ} \mathrm{C}$; and for the PRP receptor -50 cycles of $94^{\circ} \mathrm{C}$ for $30 \mathrm{~s} ; 58^{\circ} \mathrm{C}$ for $30 \mathrm{~s}$; 


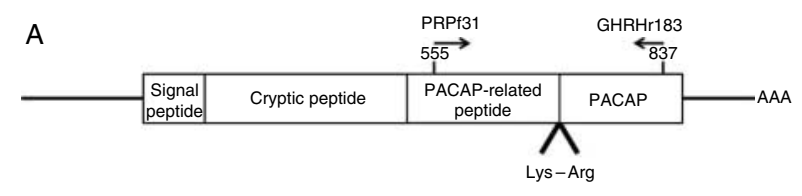

B

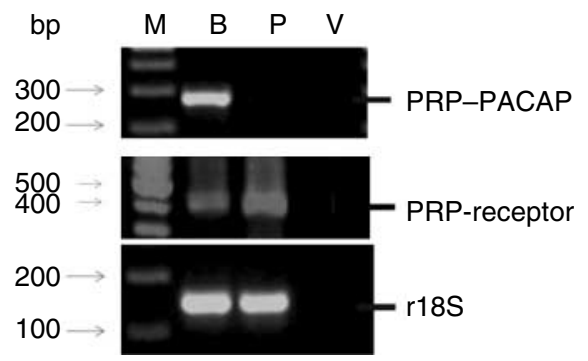

Figure 1 Expression of blue gourami PRP-PACAP and PRP receptor. Total RNA from gourami brains and pituitaries $(n=5)$ was extracted and reverse transcribed, and the resulting cDNA was amplified by PCR. (A) The location of the primer set that is specific for PRP peptide in the PRP-PACAP long transcript. (B) The lower panel shows representative results of five to ten replicates. PCR products were separated on a $2.5 \%$ agarose gel containing ethidium bromide. The predicted size of the PRP-PACAP partial fragment derived from the brain precursor was $282 \mathrm{bp}$, and the predicted size of the PRP receptor partial fragment is $405 \mathrm{bp}$. $\mathrm{r} 18 \mathrm{~s}$ - the internal PCR product control, a fragment of $150 \mathrm{bp}$, derived from gourami 18S rRNA cDNA. $B$, brain; $P$, pituitary; $V$, control without $C D N A$.

$72{ }^{\circ} \mathrm{C}$ for $30 \mathrm{~s}$. In order to validate that there were no false positive products, PCRs containing water instead of cDNA were examined. Ten microliter volumes of PCR products were analyzed by electrophoresis on a $2 \%$ agarose gel, containing ethidium bromide for visualization of DNA bands.

\section{Primary culture of dispersed pituitary cells}

Pooled pituitaries of females $(n=58)$ or males $(n=60)$ were minced with a surgical blade under a dissecting microscope with fine forceps and immediately transferred to ice-cold M-199 medium, containing $10 \mathrm{mM}$ HEPES, $0.3 \%$ BSA, $0.003 \mathrm{U} / \mathrm{ml}$ penicillin, $0.003 \mathrm{mg} / \mathrm{ml}$ streptomycin, and $0.0013 \mathrm{U} / \mathrm{ml}$ nystatin (basal medium). After incubation at $25^{\circ} \mathrm{C}$ for $1 \mathrm{~h}$, cells were dissociated by trypsin and several aspirations through a needle, followed by centrifugation at $2000 \mathrm{~g}$ for 5 min and suspension in M-199 medium, containing $10 \% \mathrm{FCS}$ and $10 \mathrm{mM}$ HEPES, $0.003 \mathrm{U} / \mathrm{ml}$ penicillin, $0.003 \mathrm{mg} / \mathrm{ml}$ streptomycin, and $0.0013 \mathrm{U} / \mathrm{ml}$ nystatin (growth medium). The cells were immediately plated in 24-well plates at a density of $3 \times 10^{5}$ cells/well for $72 \mathrm{~h}$ at $28{ }^{\circ} \mathrm{C}, 5 \% \mathrm{CO}_{2}$, and $90 \%$ humidity. Growth medium was changed to M-199 medium, containing $0.1 \%$ BSA, $10 \mathrm{mM}$ HEPES, $0.003 \mathrm{U} / \mathrm{ml}$ penicillin, $0.003 \mathrm{mg} / \mathrm{ml}$ streptomycin, and $0.0013 \mathrm{U} / \mathrm{ml}$ nystatin (stimulating medium). Following $15 \mathrm{~min}$ of incubation at $28^{\circ} \mathrm{C}$, the cells were stimulated with bgPRP or with fish fGHRH, diluted in stimulating medium. The bgPRP was synthesized, based on the first 45 amino acids of the sequence of the blue gourami mRNA (Levy et al. 2010; Genescript, Piscataway, NJ, USA), and the fGHRH was synthesized according to the first 27 amino acids of the sequence of the non-mammalian vertebrate (Lee et al. 2007; Genescript). After incubation, the medium was removed, and the cells were harvested by scraping, for RNA extraction and cDNA using verso cDNA kit (ABgene) as described above.

\section{Real-time PCR}

In order to compare the PRP-PACAPmRNA levels in the brain of the gourami individuals, or mRNA levels of the $G H, \beta L H$, and $\beta F S H$ in the primary culture of dispersed pituitary cells, the relative abundance of mRNA was normalized with the mRNA of the endogenous reference gene, $18 \mathrm{~S}$ subunit of rRNA ( $18 S \mathrm{rRNA}$ ), by the comparative threshold cycle $\left(C_{\mathrm{T}}\right)$ method, according to Pfaffl (2001). The relative amount of each gene was calculated by the formula $2^{-\Delta C_{\mathrm{T}}}$, where $\Delta C_{\mathrm{T}}$ corresponds to the difference between the $C_{\mathrm{T}}$ measured for each target gene, and that determined for $18 S \mathrm{rRNA}$. To validate this method, serial dilutions were prepared from a brain cDNA sample, and the efficiencies of gene amplifications were compared by plotting $\Delta C_{\mathrm{T}}$ versus $\log$ (template), according to the method of Muller et al. (2002). Linear regressions of the plots showed $R^{2}$ values of 0.99. Gene-specific primers for the real-time PCR (Table 1) were designed using Primer3 Software. To each of the above PCR mixtures, SYBR Green Master Mix (ABgene) was added, and amplification was carried out in a RotorGene 3000 Sequence Detection System (Corbett Research, Mortlake, Australia) under the following conditions: for PRP-PACAP - initial denaturation at $95^{\circ} \mathrm{C}$ for $15 \mathrm{~min}$, followed by 40 cycles of $95^{\circ} \mathrm{C}$ for $10 \mathrm{~s}, 60{ }^{\circ} \mathrm{C}$ for $20 \mathrm{~s}$, and $72^{\circ} \mathrm{C}$ for $20 \mathrm{~s}$; for $\beta \mathrm{LH}$ - initial denaturation at $95^{\circ} \mathrm{C}$ for $15 \mathrm{~min}$, followed by 40 cycles of $95^{\circ} \mathrm{C}$ for $10 \mathrm{~s}$, annealing at $60^{\circ} \mathrm{C}$ for $15 \mathrm{~s}$, and extension at $72^{\circ} \mathrm{C}$ for $20 \mathrm{~s}$; for $\beta F S H$ - initial denaturation at $95^{\circ} \mathrm{C}$ for $15 \mathrm{~min}$, followed by 40 cycles of $95^{\circ} \mathrm{C}$ for $10 \mathrm{~s}$, annealing at $57^{\circ} \mathrm{C}$ for $20 \mathrm{~s}$, and extension at $72^{\circ} \mathrm{C}$ for $20 \mathrm{~s}$; for $\mathrm{GH}$ - initial denaturation at $95^{\circ} \mathrm{C}$ for $15 \mathrm{~min}$, followed by 40 cycles of $95^{\circ} \mathrm{C}$ for $10 \mathrm{~s}, 64^{\circ} \mathrm{C}$ for $20 \mathrm{~s}, 72^{\circ} \mathrm{C}$ for $20 \mathrm{~s}$, and $83^{\circ} \mathrm{C}$ for $15 \mathrm{~s}$; and for $18 S r R N A$ - initial denaturation at $95^{\circ} \mathrm{C}$ for $15 \mathrm{~min}$, followed by 40 cycles of $95^{\circ} \mathrm{C}$ for $15 \mathrm{~s}, 64^{\circ} \mathrm{C}$ for $20 \mathrm{~s}$, and extension at $72{ }^{\circ} \mathrm{C}$ for $20 \mathrm{~s}$. Amplifications of each target gene and reference gene (18S rRNA) cDNAs were performed simultaneously in separate tubes in duplicates, and the results were analyzed with the Q-Gene software (Simon 2003). Dissociation curve analysis was run after each real-time experiment to ensure that there was only one product. To control for false 
positives, a non-template negative control was run for each primer pair.

\section{Statistical analysis}

Data are presented as the mean \pm s.E.M. The significance of the differences between group means of hormone mRNA levels was determined by one-way ANOVA, followed by a posteriori Bonferroni or LSD post hoc tests using SPSS version 17.0 software (SPSS Inc., Chicago, IL, USA). Differences were considered statistically significant at $P<0 \cdot 05$.

\section{Results}

\section{PRP-PACAP and PRP receptor expression in the brain and pituitary}

In order to determine whether PRP-PACAP is expressed in brains and pituitaries, total RNA from these organs of gourami fish was reverse transcribed. Reactions, using cDNA derived from brain RNA and a set of primers specific to a segment of the gourami PRP-PACAP gene (Fig. 1A), produced a $282 \mathrm{bp}$ fragment (Fig. 1B). No product was obtained from the pituitary cDNA. The PRP receptor fragment was identified in both brains and pituitaries. The expression of $\mathrm{r} 18 \mathrm{~S}$ was also measured in order to provide an internal control for the quantity of RNA template in each RT-PCR aliquot. Amplification of r18S in brain and pituitary samples gave a single product of $150 \mathrm{bp}$ (Fig. 2B), indicating that there was no degradation of RNA in the preparation of the pituitary RNA samples.

\section{The expression pattern of PRP-PACAP throughout the reproductive cycle and during sexual behavior in blue gourami females and males}

Relative mRNA levels of PRP-PACAP were determined in brains excised from females and males. The females examined were in the previtellogenic (maintained alone, without males; PV), low vitellogenic (LV), and high vitellogenic (HV) stages, or were paired with
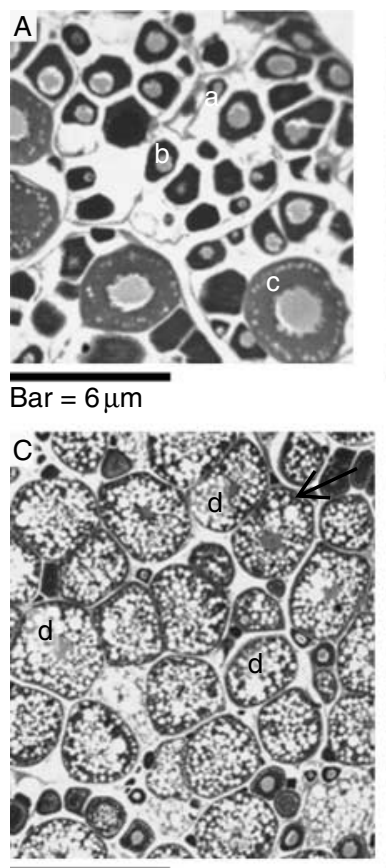

Bar $=100 \mu \mathrm{m}$

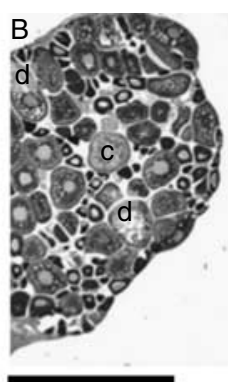

\section{$\operatorname{Bar}=100 \mu \mathrm{m}$}

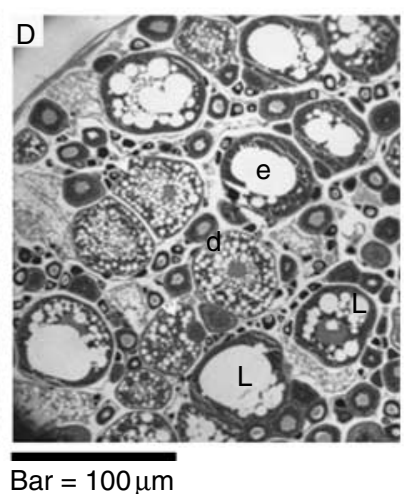

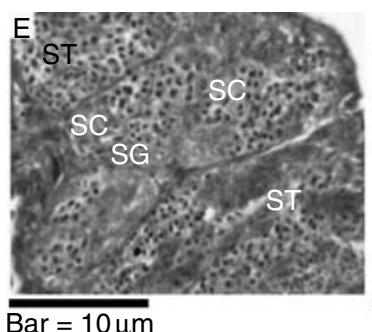
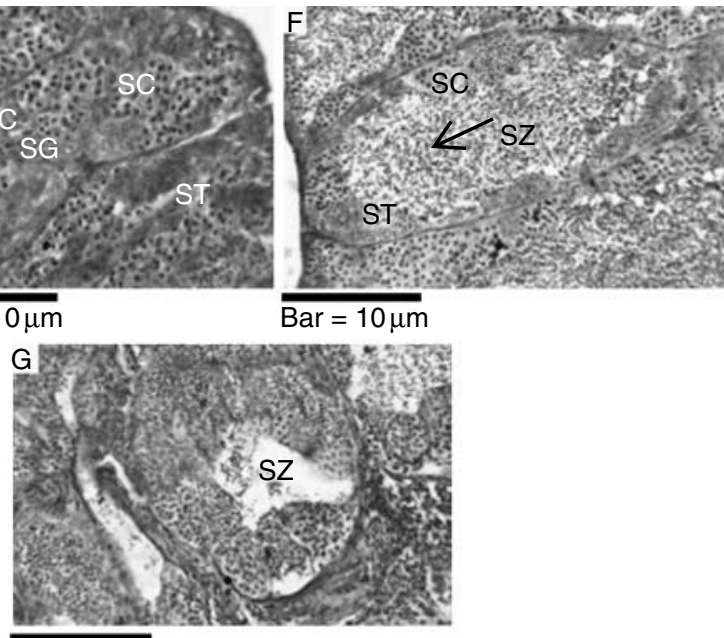

Bar $=10 \mu \mathrm{m}$

Figure 2 Histological determination of various reproductive stages in females $(A-D)$ and males $(E-G)$ of the blue gourami.

(A) Previtellogenic stage (PV). Perinuclear oocyte with an intracellular spherical structure (a). Oocyte at cortical alveolar stage (b). Note the irregular outgrowth of the nuclear periphery. (B) Low vitellogenic stage. Note the low percentage of oocytes in the advanced vitellogenic stage (c). Lipid droplets (L). (C) High vitellogenic stage. Note the high percentage of oocytes at the advance vitellogenic stage (c). Yolk vesicle accumulation (black arrow). (D) Maturation stage (MS). Note that the appearance of oocytes at the maturation stage (d) is characterized by the fusion of lipid vesicles into one vesicle (L). (E) Juvenile male. Note the absence of spermatozoa (SZ) in the middle of the lobule. (F) Mature non-reproductive male. A high concentration of SZ is observed in the middle of the lobule (black arrow). (G) Mature fish during sexual behavior. Note the decrease in the number of SZ in the center of the lobule. Cellular spermatogenesis stages are shown in E and F at the periphery of the lobule: SG, spermatogonia; SC, spermatocyte; ST, spermatids. Sections were stained with hematoxylin and eosin. 


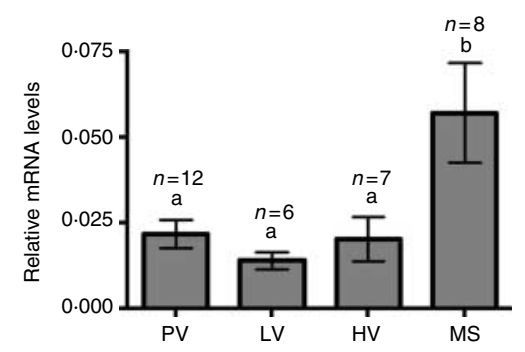

Figure 3 Relative mRNA levels of $P R P-P A C A P$ in brains from blue gourami females at different stages of oogenesis: previtellogenesis (PV), low vitellogenesis (LV), high vitellogenesis (HV), and maturation (MS). Total brain RNA was reverse transcribed, and the resulting CDNA was used in quantitative realtime PCR. The relative amount of the PRP-PACAP mRNA was normalized to that of $18 \mathrm{~S}$ rRNA by the $C_{\mathrm{T}}$ cycle method, where $2^{-\Delta C_{T}}$ reflects the relative amount of PRP-PACAP transcription. Each histogram represents the average of independent measurements (mean \pm s.E.M.; $n=5-7$ ). Different letters above the histograms denote significant differences among the mRNA levels $(P<0.05$, by ANOVA, Bonferroni post hoc test).

males to induce the final maturation stage (MS). The reproductive stage was assessed by the histology of the ovaries, presented in Fig. 2A-D. The males tested were those maintained without females, i.e. juveniles and non-reproductive adult males and males, which were reproductively active and built bubble nests. The histology of their testes is shown in Fig. 2E-G respectively. $P R P-P A C A P \mathrm{mRNA}$ levels were significantly higher in the paired, reproductively active females with oocytes in the MS, than in unpaired females (PV, LH, and HV; $2 \cdot 6-$, $4 \cdot 08-$, and $2 \cdot 81$-fold respectively) $(P<0 \cdot 05$, by ANOVA and Bonferroni post hoc test; Fig. 3). PRP-PACAP mRNA levels were significantly augmented in mature non-reproductive males, as compared to in mature reproductive (16.269-fold) and juvenile males (7.534-fold; Fig. 4). No significant difference was found between the PRP-PACAP mRNA levels of the mature reproductive fish and the juveniles.

\section{Effect of bgPRP and fGHRH on $\beta L H, \beta F S H$, and $G H$ mRNA levels in a culture of dispersed gourami pituitary cells}

In order to study the direct effect of GHRH-like peptides on the expression of pituitary genes, pituitary cells from females or males were treated with synthetic bgPRP or fGHRH, and the expression levels of $\beta \mathrm{LH}$, $\beta F S H$, and GH were determined. Figures 5 and 6 summarize the effects of bgPRP and fGHRH on pituitary hormone gene expression levels in a culture of dispersed pituitary cells of gourami females and males respectively. In females, bgPRP treatment of cells significantly increased $\beta L H$ and $\beta F S H$ mRNA levels $(2 \cdot 8$ - and $2 \cdot 5$-fold respectively), with a maximal response at $24 \mathrm{~h}$. No effect on $G H$ mRNA levels was observed (Fig. 5). In male-derived cells, bgPRP brought about a significant rise in GH mRNA levels (Fig. 6), with a maximal response at $48 \mathrm{~h}$ following treatment $(3 \cdot 7$-fold $)$. In contrast, fGHRH caused an increase in the $\beta L H$ mRNA levels, in female cells $24 \mathrm{~h}$ after treatment and in male cells $48 \mathrm{~h}$ after treatment (10.2- and $14 \cdot 8$-fold respectively); fGHRH treatment increased $G H$ mRNA levels in male-derived (97.4-fold) and in female-derived cells 24 and $48 \mathrm{~h}(2 \cdot 23-$ and $2 \cdot 27$-fold respectively) after treatment, whereas $\beta F S H$ mRNA levels rose $48 \mathrm{~h}$ following fGHRH treatment only in female-derived cells $(5 \cdot 93$-fold).

\section{Discussion}

In the present study, we show that PRP-PACAP gene expression in the brain changes during different stages of oogenesis and sexual behavior of the blue gourami male and female. In addition, the identification of the PRP receptor in the pituitary was supported by the in vitro bgPRP hypophysiotropic effect on pituitary hormone gene expression. The results showed that $P R P-P A C A P$ expression varies significantly throughout the reproductive cycle in the blue gourami males and females, and that it can up-regulate GH and gonadotropin gene expression respectively through its receptor in dispersed pituitary cell cultures.

As a preliminary step, PRP-PACAP mRNA expression was examined in the brain and pituitary of the blue gourami fish. The exclusive high expression level of PRP-PACAP in the brain is in agreement with previous reports on catfish (McRory et al. 1995), zebrafish (Fradinger \& Sherwood 2000), and lungfish

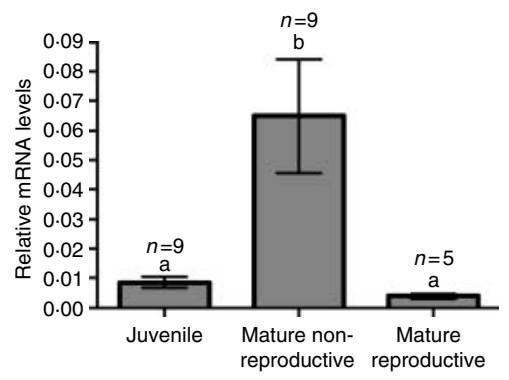

Figure 4 Relative mRNA levels of $P R P-P A C A P$ in brains from blue gourami males at different stages of reproduction: juvenile, mature non-reproductive, and mature reproductive. Total RNA from brains was reverse transcribed for quantitative real-time PCR. The relative amount of PRP-PACAP mRNA was normalized to that of $18 S$ rRNA by the $C_{\text {T }}$ cycle method, where $2^{-\Delta C_{T}}$ reflects the relative amount of the specific gene precursor transcripts. Each histogram represents the average of independent measurements (mean \pm S.E.M.; $n=4-9$ ). A different letter above the histogram denotes its significant difference from the mRNA levels of the other histograms $(P<0.05$ ANOVA and Bonferroni post hoc test). 


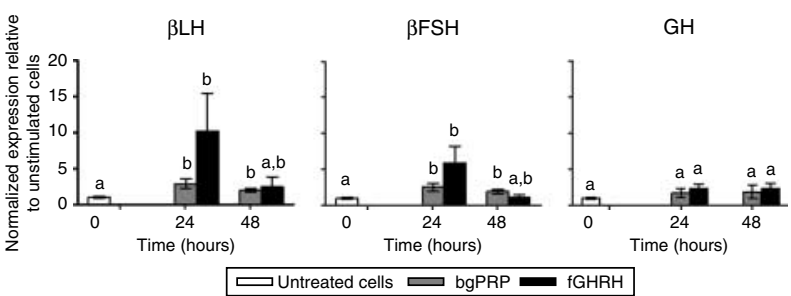

Figure 5 The effect of blue gourami PRP (bgPRP) and fish GHRH (fGHRH) on $\beta L H, \beta F S H$, and $G H$ mRNA levels in a culture of dispersed pituitary cells from gourami females. A gourami pituitary cell culture of high vitellogenic non-reproductive females was treated with the following peptides: $10 \mathrm{nM}$ of synthetic blue gourami PRP (bgPRP) or $10 \mathrm{nM}$ fish GHRH for 24 and $48 \mathrm{~h}$. Total RNA was extracted and reverse transcribed to cDNA, which was used as a template for the real-time PCR. $\beta L H, \beta F S H$, and $G H$ mRNA levels were normalized to that of $18 \mathrm{~S}$ rRNA by the $C_{\mathrm{T}}$ cycle method, where $2^{-\Delta C_{T}}$ reflects the relative amount of specific gene precursor transcripts. Each histogram represents the mRNA level of the hormone relative to that of the non-treated cells, which was set at 1 . A different letter above the histogram denotes its significant difference from the mRNA levels of the non-treated cells $(P<0.05$ ANOVA and Bonferroni post hoc test).

(Lee et al. 2009). In this study, a partial sequence of the PRP receptor transcript was identified in the brain and pituitary of the blue gourami fish as a GPCR subfamily B-I member. This partial transcript encodes for the PRP receptor and includes the following domains: TM2, TM3, TM4, and TM5, part of the ICL1 and the full sequences of ICL2, ECL1, and ECL2. They provide critical information necessary for specific interactions with ligands and intracellular signaling (Harmar 2001). This receptor might be able to bind PRP and transmit intracellular signals, which are important to the physiological relevance of bgPRP, in vivo. To date, the PRP receptor has been found to be expressed only in non-mammalian species. Among fish, the PRP receptor has been detected in goldfish, zebrafish, and fugu (Cardoso et al. 2003, Fradinger et al. 2005, Wang et al. 2010).

The presence of the PRP-PACAP transcript in the brain alone, and its receptor in the pituitary, as well, is in agreement with findings in goldfish (Chan et al. 1998) and chicken (Wang et al. 2010). They imply that PRP exerts conserved tissue-specific functions in the central nervous system in non-mammalian vertebrates and that its function might be mediated by a specific receptor.

As of yet, there have been no reports on a possible relationship between brain PRP-PACAP mRNA and reproduction in fish. In this study, $P R P-P A C A P$ expression was detected in the brain of the blue gourami females during different reproductive stages. The higher mRNA levels that were obtained in the brain of females, with oocytes at the final MS, as compared to vitellogenic and non-vitellogenic females, imply that PRP as well as PACAP peptides may be involved in the regulation of the final MS of oocytes which occurs as a result of an interaction with males. This expression pattern is in correlation with the GnRH3 expression pattern in the brain of the gourami females (Levy et al. 2009), suggesting that PRP-PACAP may be associated with the regulation of the gonadotropic axis on the hypothalamic pituitary level. These findings are not in agreement with a previous study, in which PRP-PACAP expression levels did not change during the reproductive stages in the turkey (Yoo et al. 2000). Such differences can be explained by the fact that the role of PRP has been lost through evolution, as supported by recent findings in birds, demonstrating that the PRP receptor lacks the ligand-binding domain (Wang et al. 2010).

On the other hand, in males, high expression levels of PRP-PACAP were detected only in nonreproductively active adults, which were kept separated from females. These fish were characterized by a high concentration of spermatozoa in the middle of the testes lobes and did not build a nest of bubbles. Although PRP is encoded by a single gene that also encodes PACAP, its mRNA expression pattern in males does not correlate with PACAP expression in the brain of the blue gourami male. This is because the latter can be transcribed in a short transcript, independently of the PRP-PACAP long transcript, due to the exonskipping phenomenon (Levy et al. 2010). As opposed to PRP-PACAP expression in females, in the male brain, $P R P-P A C A P$ expression does not correlate with GnRH3 expression, hinting that in males PRP-PACAP may not be involved in the regulation of the gonadotropic axis.

The expression of PRP-PACAP in the brain and of its receptor in the pituitary in the blue gourami raised the hypothesis that PRP may act as a hypophysiotropic

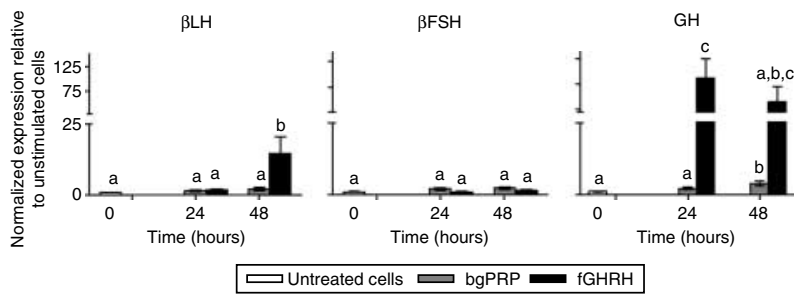

Figure 6 The effect of blue gourami PRP (bgPRP) and fish GHRH (fGHRH) on $\beta L H, \beta F S H$, and $G H$ mRNA levels in a culture of dispersed pituitary cells from gourami males. A gourami pituitary cell culture of mature non-reproductive females was treated with the following peptides: $10 \mathrm{nM}$ of synthetic blue gourami PRP (bgPRP) or $10 \mathrm{nM}$ fish GHRH for 24 and $48 \mathrm{~h}$. Total RNA was extracted and reverse transcribed to cDNA, which was used as a template for the real-time PCR. $\beta L H, \beta F S H$, and $G H$ mRNA levels were normalized to that of $18 \mathrm{~S}$ rRNA by the $C_{\mathrm{T}}$ cycle method, where $2^{-\Delta C_{T}}$ reflects the relative amount of specific gene precursor transcripts. Each histogram represents the mRNA level of the hormone relative to that of the non-treated cells, which was set at 1. A different letter above the histogram denotes its significant difference from the mRNA levels of the non-treated cells ( $P<0.05$ ANOVA and Bonferroni post hoc test). 
regulator in the blue gourami. The newly identified GHRH gene in fish (Lee et al. 2007) raised a question regarding the biological role of PRP. Because of the structural similarity between PRP and GHRH, which was noted in an earlier paper describing the gene that encodes PRP-PACAP in humans, it was suggested that PRP may act as a GH-releasing factor (Ohkubo et al. 1992).

In the chicken, a close evolutionary relationship between the GHRH receptor and the PRP receptor has been shown, however, as in the blue gourami, bgPRP, and in zebrafish, PRP-R (the zebrafish PRP receptor) shares a $40 \%$ identity with the zebrafish and the human GHRH receptor (Wang et al. 2010).

In a subsequent step, the effect of PRP on pituitary hormone gene expression was examined in a pituitary culture of dispersed cells, obtained from males or females in vitro. In addition, the effects of the nonmammalian (fish) GHRH and bgPRP were compared. A gender-related hypophysiotropic effect of bgPRP and fGHRH on pituitary hormone gene expression was demonstrated in pituitary cultures obtained from females and males. For the first time, it is shown that PRP can up-regulate both $\beta F S H$ and $\beta L H$ mRNA levels after different incubation times in pituitary cultures of dispersed cells obtained from females. In males, PRP can up-regulate only $G H$ mRNA levels. These data support previous findings that demonstrate a stimulatory effect of PRP on GH release. In the carp, PRP could stimulate $\mathrm{GH}$ release from cultured goldfish pituitary glands, and in goldfish, a PRP injection elevated GH serum levels (Vaughan et al. 1992). Synthetic carp PRP was active in releasing GH from enzymatically dispersed rainbow trout pituitary fragments in a concentration-dependent manner (Luo et al. 1990, Parker et al. 1997). These results, in addition to the PRP expression pattern in the brain of the blue gourami at different reproductive stages, imply that in females, PRP is involved in the regulation of reproduction at the transcription level of pituitary hormones.

Similar to bgPRP in in vitro assays, a sex-dependent effect of fGHRH on $\beta F S H$ and $G H$ gene expression was demonstrated in this study, probably because the receptors are structurally related (Cardoso et al. 2005). Functional assays revealed that the PRP receptors in both zebrafish and goldfish are most sensitive to one of their PRP, but both also bind GHRH (Lee et al. 2007). The increase in GH mRNA levels upon fGHRH stimulation in pituitary cells derived from males in this study is in agreement with a previous report, which showed that an i.p. injection of a human pancreatic GHRH fragment provoked an increase in serum GH levels in goldfish (Peter et al. 1984). The results of the present study also show that, as opposed to bgPRP, fGHRH may also be involved in the regulation of reproduction in males, via up-regulation of $L H$ mRNA levels. In ruminants, exogenous administration of GHRH increased GH and LH plasma levels (Mondal et al. 2006). The comparison, between the effects of bgPRP and fGHRH on pituitary hormone gene expression, implies that both GHRH and PRP systems, which exist in this fish, have different cellular receptor distribution and signal transduction pathways in males and females.

Furthermore, molecular cloning of gourami cDNA, encoding for the GHRH peptide, is clearly required to determine whether it shares a high percent of sequence similarity and the same biological activity, on the receptor, as well as on the cellular levels.

In conclusion, in this study, we report for the first time 1) a sex-related association between PRP-PACAP and growth and reproduction, 2) identification of PRP receptors in the brain and pituitary, and 3) a direct hypophysiotropic effect of PRP on hormonal gene transcription in the blue gourami fish. In females, $P R P-P A C A P$ gene expression is associated with the final MS of oocytes, as supported by in vitro up-regulation of gene expression of pituitary hormones on the gonadotropic axis. These results are in agreement with data from a previous study in our laboratory (Goldberg $e t$ al. 2004). The highest levels of $G H$ mRNA were found in immature females during $\mathrm{HV}$ and maturation. Goldberg et al. (2004) suggested that GH may play a role in the gonadal cycle of the female blue gourami. Here, high levels of $G H$ mRNA, obtained during the late stages of the gonadal cycle, validate the concept that $\mathrm{GH}$ participates in reproduction. On the other hand, in males, a higher $P R P-P A C A P$ gene expression was detected in adult non-reproductively active males, which correlates with results obtained in an in vitro up-regulation of $G H$ mRNA levels by PRP. Degani et al. (2003b) determined the mRNA level of GH in blue gourami, showing that GH levels remained high in mature males, and therefore hypothesized that $\mathrm{GH}$ may be involved in spermatogenesis. Taken together, the results of this study imply that in males, PRP may be involved in spermatogenesis, which occurs before sexual behavior (indicated by nest building) and in the release of spermatozoa during sexual behavior, but is not involved in egg fertilization.

\section{Declaration of interest}

The authors declare that there is no conflict of interest that could be perceived as prejudicing the impartiality of the research reported.

\section{Funding}

This research did not receive any specific grant from any funding agency in the public, commercial, or not-for-profit sector. 


\section{Acknowledgements}

The authors would like to thank the support of Dr Yoav Gothilf from the Department of Neurobiology in the Faculty of Life Science, Tel Aviv University, Israel.

\section{References}

Cardoso JC, Power DM, Elgar G \& Clark MS 2003 Genomic characterisation of putative growth hormone releasing hormone (GHRH) receptor genes in the teleost fish Fugu rubripes. DNA Sequence 14 129-133. (doi:10.1080/1042517031000081142)

Cardoso JC, Clark MS, Viera FA, Bridge PD, Gilles A \& Power DM 2005 The secretin G-protein-coupled receptor family: teleost receptors. Journal of Molecular Endocrinology 34 753-765. (doi:10.1677/jme.1. 01730)

Carpio Y, Lugo JM, Leon K, Morales R \& Estrada MP 2008 Novel function of recombinant pituitary adenylate cyclase-activating polypeptide as stimulator of innate immunity in African catfish (Clarias gariepinus) fry. Fish and Shellfish Immunology 25 439-445. (doi:10.1016/j.fsi.2008.06.004)

Castro A, Becerra M, Manso MJ, Tello J, Sherwood NM \& Anadon R 2009 Distribution of growth hormone-releasing hormone-like peptide: immunoreactivity in the central nervous system of the adult zebrafish (Danio rerio). Journal of Comparative Neurology 513 685-701. (doi:10.1002/cne.21977)

Chan KW, Yu KL, Rivier J \& Chow BK 1998 Identification and characterization of a receptor from goldfish specific for a teleost growth hormone-releasing hormone-like peptide. Neuroendocrinology 68 44-56. (doi:10.1159/000054349)

Degani G 1993a The effect of sexual behavior on oocyte development and steroid changes in Trichogaster trichopterus. Copeia 4 1091-1096. (doi:10.2307/1447089)

Degani G $1993 b$ Reproduction control in multi-spawning asynchronic Trichogaster trichopterus (Pallas) as a model for the anabantidae family. Trends in Comparative Biochemistry and Physiology 1 1269-1275.

Degani G \& Boker R 1992a Sensitivity to maturation-inducing steroids and gonadotropin in the oocytes of blue gourami Trichogaster trichopterus (Anabantidae, Pallas, 1770). General and Comparative Endocrinology 85 430-439. (doi:10.1016/0016-6480(92)90088-2)

Degani G \& Boker R $1992 b$ Vitellogenesis level and the induction of maturation in the ovary of the blue gourami Trichogaster trichopterus (Anabantidae, Pallas, 1770). Journal of Experimental Zoology 263 330-337. (doi:10.1002/jez.1402630313)

Degani G, Mananos EL, Jackson K, Abraham M \& Zohar Y 1997 Changes in plasma and pituitary GtH-II levels in female blue gourami Trichogaster trichopterus during the end of vitellogenesis and final oocyte maturation. Journal of Experimental Zoology 279 377-385. (doi:10.1002/(SICI) 1097-010X(19971101) 279:4<377::AID-JEZ7> 3.3.CO;2-B)

Degani G, Jackson K, Goldberg D, Sarfati R \& Avtalion RR $2003 a$ betaFSH, betaLH and growth hormone gene expression in blue gourami (Trichogaster trichopterus, Pallas, 1770) during spermatogenesis and male sexual behavior. Zoological Science 20 737-743. (doi:10.2108/zsj.20.737)

Degani G, Tzchori I, Yom-Din S, Goldberg D \& Jackson K $2003 b$ Growth differences and growth hormone expression in male and female European eels [Anguilla anguilla (L.)]. General and Comparative Endocrinology 134 88-93. (doi:10.1016/S0016-6480(03) 00238-7)

Degani G, Jackson K, Yom-Din S \& Goldberg D 2006 cDNA cloning and mRNA expression of growth hormone in belontiidae (Anabantoidei suborder). Israeli Journal of Aquaculture 58 124-136.

Fradinger EA \& Sherwood NM 2000 Characterization of the gene encoding both growth hormone-releasing hormone (GRF) and pituitary adenylate cyclase-activating polypeptide (PACAP) in the zebrafish. Molecular and Cellular Endocrinology 165 211-219. (doi:10. 1016/S0303-7207(00)00251-3)

Fradinger EA, Tello JA, Rivier JE \& Sherwood NM 2005 Characterization of four receptor cDNAs: PAC1, VPAC1, a novel PAC1 and a partial GHRH in zebrafish. Molecular and Cellular Endocrinology 231 49-63. (doi:10.1016/j.mce.2004.12.002)

Goldberg D, Jackson K, Yom-Din S \& Degani G 2004 Growth hormone of Trichogaster trichopterus: cDNA cloning, sequencing and analysis of mRNA expression during oogenesis. Journal of Aquaculture in the Tropics 19 215-229.

Goth MI, Lyons CE, Canny BJ \& Thorner MO 1992 Pituitary adenylate cyclase activating polypeptide, growth hormone $(\mathrm{GH})$-releasing peptide and GH-releasing hormone stimulate GH release through distinct pituitary receptors. Endocrinology 130 939-944. (doi:10. $1210 /$ en.130.2.939)

Harmar AJ 2001 Family-B G-protein-coupled receptors. Genome Biology 2 REVIEWS3013. (doi:10.1186/gb-2001-2-12-reviews3013)

Jackson K, Abraham M \& Degani G 1994 Oocyte maturation triggered by the presence of male in the blue gourami (Trichogaster trichopterus). Journal of Morphology 220 1-9. (doi:10.1002/jmor. 1052200102)

Jackson K, Goldberg D, Ofir M, Abraham M \& Degani G 1999 Blue gourami (Trichogaster trichopterus) gonadotropic beta subunits (I and II) cDNA sequences and expression during oogenesis. Journal of Molecular Endocrinology 23 177-187. (doi:10.1677/jme.0. 0230177)

Lee LT, Siu FK, Tam JK, Lau IT, Wong AO, Lin MC, Vaudry H \& Chow BK 2007 Discovery of growth hormone-releasing hormones and receptors in nonmammalian vertebrates. PNAS 104 2133-2138. (doi:10.1073/pnas.0611008104)

Lee LT, Tam JK, Chan DW \& Chow BK 2009 Molecular cloning and mRNA distribution of pituitary adenylate cyclase-activating polypeptide (PACAP)/PACAP-related peptide in the lungfish. Annals of the New York Academy of Sciences 1163 209-214. (doi:10.1111/j.17496632.2008.03661.x)

Levy G, Gothilf Y \& Degani G 2009 Brain gonadotropin releasing hormone 3 expression variation during oogenesis and sexual behavior and its effect on pituitary hormonal expression in the blue gourami. Comparative Biochemistry and Physiology. Part A, Molecular and Integrative Physiology 154 241-248. (doi:10.1016/j. cbpa.2009.06.010)

Levy G, Jackson K \& Degani G 2010 Association between pituitary adenylate cyclase-activating polypeptide and reproduction in the blue gourami. General and Comparative Endocrinology 166 83-93. (doi:10.1016/j.ygcen.2009.09.015)

Luo D \& McKeown BA 1989 Immunohistochemical detection of a substance resembling growth hormone-releasing factor in the brain of the rainbow trout (Salmo gairdneri). Experientia 45 577-580. (doi:10.1007/BF01990512)

Luo DS, McKeown BA, Rivier J \& Vale W 1990 In vitro responses of rainbow trout (Oncorhynchus mykiss) somatotrophs to carp growth hormone-releasing factor (GRF) and somatostatin. General and Comparative Endocrinology 80 288-298. (doi:10.1016/0016-6480(90) 90173-J)

Mananos E, Zohar Y \& Degani G 1997 The relationship between gonadotropin and sexual behavior of male Trichogaster trichopterus (Pallas). Indian Journal of Fisheries 44 239-246.

McRory JE, Parker DB, Ngamvongchon S \& Sherwood NM 1995 Sequence and expression of cDNA for pituitary adenylate cyclase activating polypeptide (PACAP) and growth hormone-releasing hormone (GHRH)-like peptide in catfish. Molecular and Cellular Endocrinology 108 169-177. (doi:10.1016/0303-7207(94)03467-8)

Mondal M, Rajkhowa C \& Prakash BS 2006 Exogenous GH-releasing hormone increases $\mathrm{GH}$ and $\mathrm{LH}$ secretion in growing mithuns (Bos frontalis). General and Comparative Endocrinology 149 197-204. (doi:10.1016/j.ygcen.2006.05.010) 
Montero M, Yon L, Kikuyama S, Dufour S \& Vaudry H 2000 Molecular evolution of the growth hormone-releasing hormone/pituitary adenylate cyclase-activating polypeptide gene family. Functional implication in the regulation of growth hormone secretion. Journal of Molecular Endocrinology 25 157-168. (doi:10.1677/jme.0. 0250157)

Muller PY, Janovjak H, Miserez AR \& Dobbie Z 2002 Processing of gene expression data generated by quantitative real-time RT-PCR. Biotechniques 32 1372-1374, 1376, 1378-1379.

Ohkubo S, Kimura C, Ogi K, Okazaki K, Hosoya M, Onda H, Miyata A, Arimura A \& Fujino M 1992 Primary structure and characterization of the precursor to human pituitary adenylate cyclase activating polypeptide. DNA and Cell Biology 11 21-30. (doi:10.1089/dna.1992. 11.21)

Olivereau M, Olivereau J \& Vandesande F 1990 Localization of growth hormone-releasing factor-like immunoreactivity in the hypothalamo-hypophysial system of some teleost species. Cell and Tissue Research 259 73-80. (doi:10.1007/BF00571432)

Pan JX, Lechan RM, Lin HD \& Jackson IM 1985 Immunoreactive neuronal pathways of growth hormone-releasing hormone (GRH) in the brain and pituitary of the teleost Gadus morhua. Cell and Tissue Research 241 487-493. (doi:10.1007/BF00214567)

Parker DB \& Sherwood NM 1990 Evidence of a growth hormonereleasing hormone-like molecule in salmon brain, Oncorhynchus keta and O. kisutch. General and Comparative Endocrinology 79 95-102. (doi:10.1016/0016-6480(90)90092-Z)

Parker DB, Power ME, Swanson P, Rivier J \& Sherwood NM 1997 Exon skipping in the gene encoding pituitary adenylate cyclase-activating polypeptide in salmon alters the expression of two hormones that stimulate growth hormone release. Endocrinology 138 414-423. (doi:10.1210/en.138.1.414)

Peter RE, Nahorniak CS, Vale WW \& Rivier JE 1984 Human pancreatic growth hormone-releasing factor (hpGRF) stimulates growth hormone release in goldfish. Journal of Experimental Zoology 231 161-163. (doi:10.1002/jez.1402310121)

Pfaffl MW 2001 A new mathematical model for relative quantification in real-time RT-PCR. Nucleic Acids Research 29 e45. (doi:10.1093/ nar/29.9.e45)

Rao SD, Rao PD \& Peter RE 1996 Growth hormone-releasing hormone immunoreactivity in the brain, pituitary, and pineal of the goldfish, Carassius auratus. General and Comparative Endocrinology 102 210-220. (doi:10.1006/gcen.1996.0062)
Rousseau K, LeBelle N, Pichavant K, Marchelidon J, Chow BK, Boeuf G \& Dufour S 2001 Pituitary growth hormone secretion in the turbot, a phylogenetically recent teleost, is regulated by a species-specific pattern of neuropeptides. Neuroendocrinology 74 375-385. (doi:10. $1159 / 000054704)$

Sherwood NM, Krueckl SL \& McRory JE 2000 The origin and function of the pituitary adenylate cyclase-activating polypeptide (PACAP)/ glucagon superfamily. Endocrine Reviews 21 619-670. (doi:10.1210/ er.21.6.619)

Simon P 2003 Q-Gene: processing quantitative real-time RT-PCR data. Bioinformatics 19 1439-1440. (doi:10.1093/bioinformatics/btg157)

Tam JK, Lee LT \& Chow BK 2007 PACAP-related peptide (PRP) molecular evolution and potential functions. Peptides 28 1920-1929. (doi:10.1016/j.peptides.2007.07.011)

Vaudry D, Falluel-Morel A, Bourgault S, Basille M, Burel D, Wurtz O, Fournier A, Chow BK, Hashimoto H, Galas L et al. 2009 Pituitary adenylate cyclase-activating polypeptide and its receptors: 20 years after the discovery. Pharmacological Reviews 61 283-357. (doi:10. 1124/pr.109.001370)

Vaughan JM, Rivier J, Spiess J, Peng C, Chang JP, Peter RE \& Vale W 1992 Isolation and characterization of hypothalamic growth hormone releasing factor from common carp, Cyprinus carpio. Neuroendocrinology 56 539-549. (doi:10.1159/000126272)

Wang Y, Li J, Wang CY, Kwok AY, Zhang X \& Leung FC 2010 Characterization of the receptors for chicken GHRH and GHRHrelated peptides: identification of a novel receptor for GHRH and the receptor for GHRH-LP (PRP). Domestic Animal Endocrinology 38 13-31. (doi:10.1016/j.domaniend.2009.07.008)

Wong AO, Li WS, Lee EK, Leung MY, Tse LY, Chow BK, Lin HR \& Chang JP 2000 Pituitary adenylate cyclase activating polypeptide as a novel hypophysiotropic factor in fish. Biochemistry and Cell Biology 78 329-343. (doi:10.1139/bcb-78-3-329)

Yoo SJ, You S, Kim H, Kim SC, Choi YJ, El Halawani M, Farris J \& Foster DN 2000 Molecular cloning and characterization of alternatively spliced transcripts of the turkey pituitary adenylate cyclaseactivating polypeptide. General and Comparative Endocrinology 120 326-335. (doi:10.1006/gcen.2000.7567)

Received in final form 2 December 2010

Accepted 12 January 2011

Made available online as an Accepted Preprint 12 January 2011 